\title{
書 評 Book Review
}

\author{
Zoltan Papp: Obstetric Genetics
}

Akademiai Kiado, Budapest, xxv+627pp., 1990, $\$ 89.00$

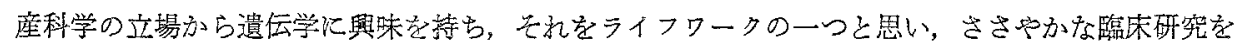
行ってきた一人として，最近らっと思うことがある，それは，遺伝が生殖現象を介して現実のるのと なるのならば，上卜生殖をフィールドとする産科学に叔いて何故遺伝学の研究が余り進んでいないの

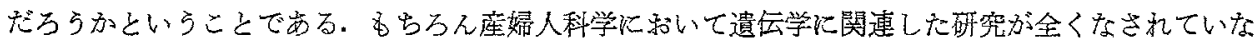

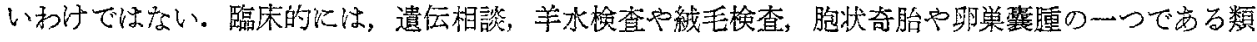

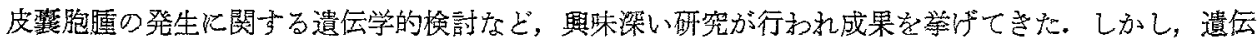

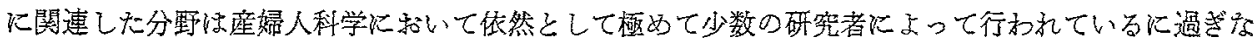
い、い放ば研究者の層が極めて薄いのである。

これ性科学の歷史が長い間，分婏の夕関する学問であったからに他ならない，助産学であった

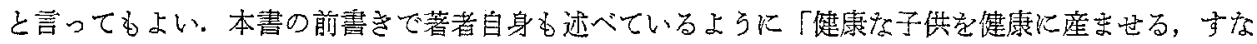

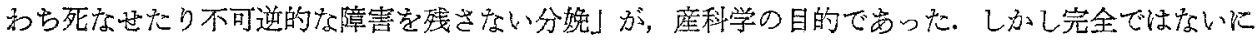

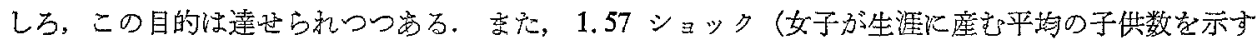
合計特殊出生率が 1989 年度に 1.57 にさで低下した）と言われるような，わが国の举児数の著しい

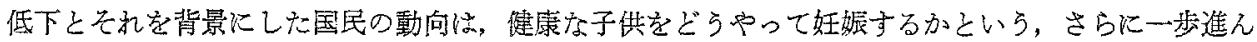

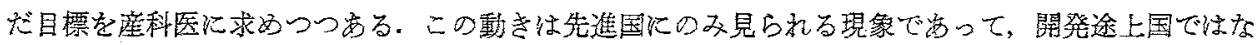

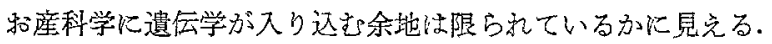

このように，先進国にあっては産科医の溉でる遺伝学化無関心ではいられなくなってているし，

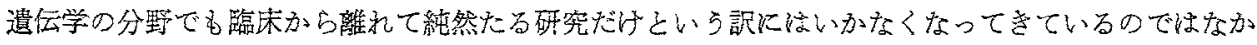

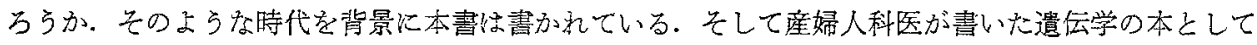
は極めて広範团で，かつ，このような広籍困な分野をカバーしているという点では私が知る限り最初 のものでらる.

本書は 80 章という膨大な粠成でなっている、最初から 11 章までは臨床遺伝学から始委って DNA

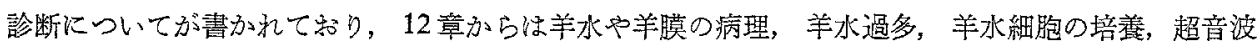

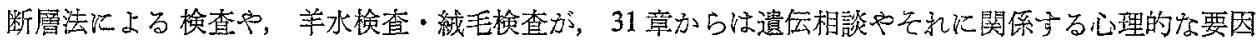

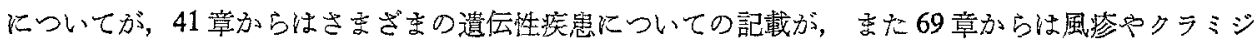

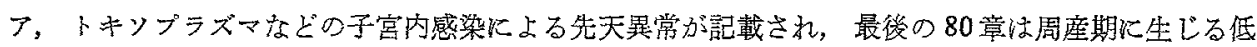
酸素正などによる障害についてが記載されている。かなり膨大な領域について記載されて蚛り，すべ てがー人で書かれたかどうか正直言って疑問になってしまらぐらいである。しかし前書きの中で著者

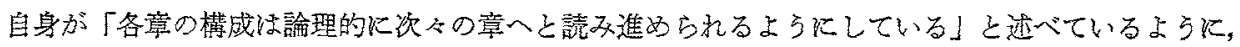

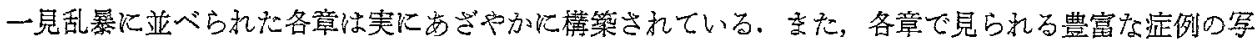
真は，20年余放心る著者自身の医師としての集大成方この書であることを示している，産科机

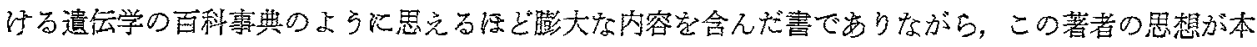
書の中のいたるとこるに明確に示されている.

産婦人科医にとってみれば，本憲仿遗伝学の産科学への関与を知る上で参考になるし，産科学以外

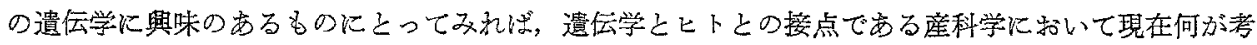

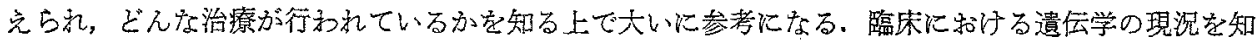
る上ではたいいて参考沉るる青である。

（佐藤孝道 虎の門病院産婦人科） 